\title{
Salivary proteins as biomarkers in dental caries: In vivo study
}

\author{
Nireeksha ${ }^{1}$, Mithra N Hegde ${ }^{2 *}$, Suchetha Kumari N ${ }^{3}$, Harshini Ullal ${ }^{4}$ and Vishakh Kedilaya ${ }^{5}$ \\ ${ }^{1}$ III Year Post Graduate, Department Of Conservative Dentistry and Endodontics, A.B.Shetty Memorial Institute of Dental Sciences, Nitte University, Deralkatte, \\ Mangalore, India \\ ${ }^{2}$ Vice Dean, Dean Of Faculty of Dental Sciences, Head of the Department, Department of Conservative Dentistry and Endodontics, A.B.Shetty Memorial Instituite \\ of Dental Sciences, Nitte University, Deralkatte Mangalore, India \\ ${ }^{3}$ Professor, Department of Biochemistry, K.S.Hegde Medical Academy, Nitte University, Deralkatte, Mangalore, India \\ ${ }^{4}$ Research Assistant, Central Research Laboratory, Kshema Nitte University, Deralkatte, Mangalore, India \\ ${ }^{5}$ Research Scholar, Central Research Laboratory, Kshema Nitte University, Deralkatte, Mangalore, India
}

\begin{abstract}
The aim of the study was to determine the relationship between salivary proteins and dental caries.

80 patients reporting to the Department of Conservative Dentistry and Endodontics, A.B.Shetty Memorial Institute of Dental Sciences, Deralkatte Mangalore, under the age group of 25-40yrs between Nov 2014- August 2016 wereselected based on inclusion criteria.

80 healthy adults were further divided into caries free $(\mathrm{N}=20)$ and caries active $(\mathrm{N}=60)$ based on DMFT index. Caries active was further divided into group I $(\mathrm{D}=1-3)$, group II ( $\mathrm{D}=4-10)$, group III $(\mathrm{D}=>10)$. Saliva samples collected were further analysed for salivary total protein levels, salivary IgA levels, salivary mucin levels, salivary albumin/globulin ratio, salivary C-reactive protein levels and proline rich proteins. The data was then statistically analysed using one way ANOVA test and Post Hoc Tukey's test. P value $<0.05$ was considered as statistically significant. Study showed significantly high levels of salivary total protein, salivary IgA and salivary albumin globulin ratio in caries free group. Salivary mucin and salivary C-reactive protein levels were significantly high in caries active group. 95\% proline rich protein bands were present in caries free group, whereas caries active group showed $65 \%$ proline rich protein bands. This study adds to better understanding of salivary components and their role in dental caries. Modulation of these proteins could play an important role in determining the onset and progression of caries, opening a new avenue of caries prevention.
\end{abstract}

\section{Introduction}

Dental caries is a multi-factorial disease and is one of the most common oral health problems in many countries. It is caused by complex interactions among acid-producing bacteria, fermentable carbohydrates and many host factors including saliva. One of the main causative agent of this condition being bacteria [1].

Saliva plays an important role in maintenance of oral health and physiology. It has been proved to be a credible diagnostic aid in detecting different biomarkers. It contains necessary elements for host protection, thus is useful for oral diagnostics. Various protective functions of salivary proteins on teeth integrity, including cleaning teeth, protecting against abrasion and attrition, retarding demineralization, promoting remineralisation, rapidly neutralizing acids, and defending the oral cavity from infection [2] .Saliva contains a large number of proteins that participate in the protection of the oral tissue, for instances lysozyme, lactoferrins, lactoperoxidase, immunoglobulinsaggluttin, albumin, mucins, histatins, defensins and immunoglobulins [2].

Salivary proteins are implied to protect oral cavity by protecting against wear by a film of salivary mucins and proline-rich glycoprotein, early pellicle proteins, proline-rich proteins, statherin. Also promote remineralization of the enamel by attracting calcium ions, retarding demineralization by the pellicle proteins, in concert with calcium and phosphate ions in saliva. Salivary (glyco) proteins prevent the adherence of oral microorganisms to the enamel pellicle and inhibit their growth [2].

The salivary bicarbonate/carbonate buffer system is responsible for rapid neutralization of acids. In contest with the various microorganisms in the oral cavity the dispersed armory of salivary proteins are necessary as they prevent rapid overgrowth of microorganisms and maintaining a stable ecosystem in the oral cavity [2].

The salivary immunoglobulin's make up about $5-15 \%$ of total salivary proteins. It is synthesized by B lymphocytes located in the vicinity of secretory epithelia. Once secreted into the interstitial

Correspondence to: Mithra N Hegde, Vice Dean, Dean Of Faculty of Dental Sciences, Head of the Department, Department of Conservative Dentistry and Endodontics, A.B.Shetty Memorial Instituite of Dental Sciences, Nitte University, Deralkatte Mangalore, India, Tel: 9845284411, E-mail: drhegdedentist@gmail.com

Key words: salivary proteins, siga, mucin, c-reactive protein, proline rich proteins, albumin globulin

Received: January 16, 2017; Accepted: January 30, 2017; Published: February 02,2017 
fluid, it is taken up by acinar and ductal cells of the salivary gland and subsequently secreted into saliva. They bind to majority of microorganisms present in saliva, thus producing a broad-spectrum defence system which prevents bacterial colonization and adherence [2].

Mucins constitute $20-30 \%$ of salivary proteins; they are divided into high molecular weight and low molecular weight mucins. They adhere to the tooth surface, lubricate, provide protection against bacteria and mechanical wear [2].

Salivary Proline rich proteins account for $25-30 \%$ of all proteins in saliva. Due to its high affinity to hydroxyapatite, it binds to the free calcium and inhibits enamel crystal growth. Basic PRP's in whole saliva attaches to the major adhesion antigen on surface of S.Mutans, protecting the surface of tooth from caries. Thus greater the basic PRP's greater the adhesion and acid neutralization in biofilms. These proteins adhere strongly to the tooth surface and expose a previously cryptic binding site for bacteria within the non - binding C-terminal domain [3].

C-reactive protein is a systemic marker that is released during acute phase of inflammatory response. These $\mathrm{C}$-reactive proteins produced in liver reaches saliva via GCF/salivary glands and this has shown to be efficient biomarker in chronic and aggressive periodontitis [4].

Proteomics is a powerful approach for biomedical research since it directly studies the key role components of biochemical systems and the cellular targets of therapeutics agents. To evaluate the typical proteomic pattern, the separation of proteins and their visualization using a stain is necessary. Gel electrophoresis is one of the important tools available to separate proteins based on their relative mobility on application of electric current depending on the molecular mass for evaluation [5-10].

Many studies were conducted regarding the relation of salivary proteins as biomarkers in dental caries but in different geographical population. This study will be specifically done on south Indian population to analyse proteins in the saliva.

Thus, classifying individuals as caries susceptible individuals or not based on salivary biomarkers present in the saliva. This helps in conducting health programmes in order enhance health and hygiene habits.

\section{Materials and methods}

After obtaining the approval by the institutional ethical committee, the study was conducted in Central Research Laboratory, NITTE University.

\section{Subjects}

Among the patients reporting to the Outpatient Department of Conservative Dentistry and Endodontics, A.B.Shetty Memorial Institute of Dental Sciences, in the age group of 25-40 years between November 2014 to August 2017 were selected based on the inclusion and exclusion criteria.

\section{Inclusion criteria}

- Free of systemic or local diseases which affects salivary secretion

- Patients willing to consent to be a part of the study.

- Patient under the age group of 25-40 yrs.

\section{Exclusion criteria}

- Patients with periodontal diseases, hypertension, diabetes, radiotherapy, chemotherapy, systemic diseases of the vital organs, history of long term medication.

- Patients under restricted diet will be excluded from the study.

- Exposition to fluoride during tooth development.

\section{Procedure}

\section{Calculation of DMFT index}

The smooth occlusal surface of the teeth was cleaned with soft bristle brush, cleaned, dried and examined and DMFT index was calculated.

\section{Groups}

Based on the DMFT index the patients were categorized as follows:

Caries free $(n=20)$, Caries active $(n=60)$

\section{Collection of saliva for salivary analysis}

Unstimulated saliva samples were collected. Subjects were asked to abstain from smoking brushing of teeth, use of mouthwash, eat/drink for 2 hour prior to the sample collection. Sample was collected between $10.00 \mathrm{am}-11.00 \mathrm{am}$.

During sample collection subject was seated in a normal chair instead of dental chair to maintain stress free environment .Once saliva is pooled in the floor of the mouth $5 \mathrm{ml}$ was collected in a Tarson's saliva collection tube. Five millilitres of saliva was collected from the patient, centrifuged, and the supernatant obtained was stored at $4^{\circ} \mathrm{C}$ for subsequent analysis.

\section{Estimation of salivary total protein level}

Salivary total protein levels were estimated using commercially available kit(AGAPPE). The collected samples were evaluated for total protein based on principle of biuret reaction (copper salt in an alkaline medium). Proteins in saliva samples form a blue colored complex when treated with cupric ions in alkaline solution. The intensity of this blue colour is proportional to protein concentration, which was calorimetrically analysed at $546 \mathrm{~nm}$ and calculated using this formula:

$$
\text { Total protein Conc. }(\mathrm{g} / \mathrm{dL})=\frac{\text { Absorbance of sample }}{\text { Absorbance of standard }} \quad \text { x } 6
$$

\section{Estimation of salivary IgA levels}

Salivary immunoglobulin levels were estimated using commercially available kiy(AGAPPE). Antibodies to Ig A and IgA in patient's saliva, forms immune complexes. These immune complexes cause an increase in light scattering. This light scattering was measured by reading at 700 $\mathrm{nm}$.

\section{Estimation of mucin levels}

Saliva samples that were collected in test tubes were diluted further using distilled water. Estimation of Mucin was performed by alcian blue in $50 \mathrm{mM}$ sodium acetate, which was further incubated under continuous agitation in room temperature for $30 \mathrm{~min}$. Samples were centrifuged at $3000 \mathrm{rpm}$ for $20 \mathrm{~min}$.

$1 \mathrm{ml} \mathrm{90 \%} \mathrm{ethanol} \mathrm{was} \mathrm{added} \mathrm{and} \mathrm{vortexed} \mathrm{for} 10 \mathrm{sec}$. Sample were centrifuged for $20 \mathrm{~min}$ at $3000 \mathrm{rpm}$ after $5 \mathrm{~min}$. Under vigorous shaking aerosol OT and equal quantity of ethyl ether was added. After centrifuging at $3000 \mathrm{rpm}$ for $15 \mathrm{~min}$, optical density was measured at $605 \mathrm{~nm}$. 


\section{Estimation of $\mathrm{C}$ - reactive protein}

Salivary C-Reactive proteins were estimated using commercially available kit (AGAPPE). The principle of estimation is based on turbidimetricimmunoassay. The C-reactive protein samples bind to specific anti-CRP antibodies, which have been absorbed to latex particles and agglutinates. The agglutination is proportional to the quality of C-reactive protein in the sample. The actual concentration is then determined by interpolation from calibration curve prepared from calibrators of known concentrations (Agappe CRP calibrator are used for the analysis).

\section{Estimation of albumin}

Salivary albumin levels were estimated using commercially available kit (AGAPPE).The reaction between albumin from saliva and the dye bromocresol green produces a change in colour that is proportional to the albumin concentration.

\section{Estimation of globulin}

Globulin is calculated by subtracting the measured albumin from the measured total protein.

Globulin = Total Protein - Albumin

Estimation of salivary proline rich proteins:

Procedure: Preparation of separating gel $(10 \%)($ total volume $=5$ ml)

Making SDS-PAGE gel:

- $\quad 2 \mathrm{ml} \mathrm{ddH_{2 } \mathrm { O }}$

- $\quad 1.67 \mathrm{ml} \mathrm{30 \%} \mathrm{acrylamide/Bis}$

- $\quad 1.25 \mathrm{ml} 1.5 \mathrm{M}$ Tris (pH 8.8)

- $\quad 25 \mu \mathrm{l} 20 \%$ SDS

- $\quad 25 \mu \mathrm{l} 10 \%$ ammonium persulfate (freshly prepared and stored at $4^{\circ} \mathrm{C}$ up to a month)

- $\quad 2.5 \mu \mathrm{l}$ TEMED (added it right before el is poured )

To avoid polymerization, after adding TEMED, the constituents were mixed well and quickly gel solution was transferred by using 1 $\mathrm{ml}$ pipette to the casting chamber between the glass plates and filled up to about $0.7 \mathrm{~cm}$ below the bottom of comb where the comb is in place.

A small layer of isopropanol is added to the top of the gel prior to polymerization to straighten the level of the gel [11-13].

Once the gel has polymerized, stacking gel was prepared (5\%) as follows (total volume $=3 \mathrm{ml}$ )

- $\quad 2.088 \mathrm{ml} \mathrm{dH}_{2} \mathrm{O}$

- $\quad 0.506 \mathrm{ml} \mathrm{30 \%} \mathrm{acrylamide/Bis}$

- $\quad 0.375 \mathrm{ml} 1 \mathrm{M}$ Tris (pH 6.8)

- $\quad 15 \mu \mathrm{l} 20 \%(\mathrm{w} / \mathrm{v})$ SDS

- $\quad 15 \mu \mathrm{l} 10 \%$ ammonium persulfate

- $\quad 1.5 \mu \mathrm{l}$ TEMED (added just before the gel is poured)

Isopropanol layer was removed by using filter paper. Top layer of the gel with was rinsed double distilled water and dried off using filter paper.
TEMED was added and mixed with stacking gel solution and content was quickly transferred by using $1 \mathrm{ml}$ pipette till the space was filled and then an appropriate comb was inserted. The top position was allowed to solidify and comb was carefully removed.

\section{Protein precipitation}

Protein precipitation was done using ice cold acetone and tricholoacetic acid. $500 \mathrm{ml}$ of the saliva was mixed with $500 \mathrm{ml}$ of TCA (20\%), acetone (90\%), ethanol (0.07\%) mixture. It was further incubated overnight at $-20^{\circ} \mathrm{C}$ and centrifuged at $1500 \mathrm{rpm}$ at $4{ }^{\circ} \mathrm{C}$ for 30 min. Pellet was then washed with $200 \mu \mathrm{l}$ cold acetone containing $0.07 \%$ 2 - $\beta$ mercaptoethanol. All the samples were subjected to SDS- PAGE.

\section{Electrophoresis}

Gel cassette were removed from the casting stand and placed on the electrode assembly with the short plate inside. Electrode assembly was presses down while clamping the frame to secure the electrode assemble and the clamped frame was put onto the electrophoresis tank.

$1 \mathrm{X}$ electrophoresis was added into the opening of the casting frame between the gel cassettes. Enough buffer was added to fill the wells of the gel. 1X buffer was added to region outside the frame.

Electrophoresis was done at $100 \mathrm{~V}$ for around $3.4 \mathrm{hrs}$ and then it was removed carefully for staining using coomasie blue.

\section{Statistical analysis}

Statistical analysis was performed using IBM SPSS statistics, Version 22 (Armonk,NY: IBM Corp). Descriptive statistics were presented in the form of mean and standard deviation. Salivary total protein levels, sIg A,C- reactive protein, Albumin globulin ratio, Salivary mucin levels were compared between the study groups using One way ANOVA test followed by Tukey's post hoc test. $\mathrm{P}<0.05$ was considered statistically significant.

\section{Results}

\section{Salivary total protein levels}

The mean total protein value in caries free group was $2.04 \mathrm{~g} / \mathrm{dL}$. In caries active group mean values were group I $(1.71 \mathrm{~g} / \mathrm{dL})$, group II $(0.82$ $\mathrm{g} / \mathrm{dL})$ and group III $(0.51 \mathrm{~g} / \mathrm{dL})$ respectively (Table 1$)$. It was shown that total protein level in caries active group decreased with increase in caries prevalence. There was a significant difference in the total protein levels among the study groups $(\mathrm{p}<0.05)$ (Table $2 \mathrm{a})$.

On pair wise comparison the difference in the total protein levels were found to be statistically significant between all the study groups (Table 2b).

\section{Salivary IgA levels}

The mean salivary Ig A value in caries free group was $10.88 \mathrm{mg} /$

Table 1. Selection of subjects.

\begin{tabular}{|l|c|c|}
\hline GROUPS & N & DMFT INDEX \\
\hline $\begin{array}{l}\text { Caries Free group: } \\
\text { CONTROL }\end{array}$ & $\mathbf{2 0}$ & $\mathbf{0}$ \\
\hline Caries active group: & & \\
\hline GROUP I & $\mathbf{2 0}$ & $\mathbf{1 - 3}$ \\
\hline GROUP II & $\mathbf{2 0}$ & $\mathbf{4 - 1 0}$ \\
\hline GROUP III & $\mathbf{2 0}$ & $>\mathbf{1 0}$ \\
\hline
\end{tabular}

$\mathrm{P}<0.05$ was considered statistically significant. Statistical comparisons were performed by one way ANOVA. 
Table 2a. Salivary total protein levels in caries free and caries active groups.

\begin{tabular}{|l|c|c|c|c|}
\hline & $\begin{array}{c}\text { Mean Salivary } \\
\text { total protein } \\
\text { levels(g/dL) }\end{array}$ & S.D & \multicolumn{2}{|c|}{ ANOVA } \\
\cline { 1 - 2 } & 2.04 & 0.258 & 135.13 & $<0.001^{*}$ \\
\hline Caries free & \multicolumn{2}{|c|}{} & & \\
\hline Caries active & \multicolumn{2}{|c|}{ F } & & \\
\hline Group I & 1.71 & 0.417 & & \\
\hline Group II & 0.82 & 0.206 & & \\
\hline Group III & 0.51 & 0.164 & & \\
\hline
\end{tabular}

${ }^{*} \mathrm{p}<0.05$ statistically significant.

Table 2b.Pair wise comparison of salivary total protein levels among caries free and caries activegroups.

\begin{tabular}{|c|c|c|c|c|c|c|}
\hline (I) Group & (J) Group & $\begin{array}{c}\text { Mean } \\
\text { Difference } \\
\text { (I-J) }\end{array}$ & $\begin{array}{c}\text { Std. } \\
\text { Error }\end{array}$ & p-value & \multicolumn{2}{|c|}{$\begin{array}{c}\text { 95\% Confidence } \\
\text { Interval }\end{array}$} \\
\cline { 3 - 7 } & & & & $\begin{array}{c}\text { Lower } \\
\text { Bound }\end{array}$ & $\begin{array}{c}\text { Upper } \\
\text { Bound }\end{array}$ \\
\hline \multirow{2}{*}{$\begin{array}{c}\text { Caries } \\
\text { free }\end{array}$} & Group I & 0.334 & 0.088 & $0.002^{*}$ & 0.103 & 0.565 \\
\cline { 2 - 7 } & Group II & 1.228 & 0.088 & $<0.001^{*}$ & 0.997 & 1.459 \\
\cline { 2 - 7 } & Group III & 1.531 & 0.088 & $<0.001^{*}$ & 1.300 & 1.763 \\
\hline Group I & Group II & 0.894 & 0.088 & $<0.001^{*}$ & 0.663 & 1.125 \\
\cline { 2 - 7 } & Group III & 1.197 & 0.088 & $<0.001^{*}$ & 0.966 & 1.428 \\
\hline Group II & Group III & 0.303 & 0.088 & $0.005^{*}$ & 0.072 & 0.535 \\
\hline
\end{tabular}

Tukey Post Hoc test, ${ }^{*} \mathrm{p}<0.05$ statistically significant, $\mathrm{p}>0.05$ Non significant, NS

Table 3a. Salivary immunoglobulin levels in caries free and caries active group.

\begin{tabular}{|l|c|c|c|c|}
\hline & $\begin{array}{c}\text { Salivary immunoglobulin } \\
\text { levels (mg/dl) }\end{array}$ & S.D & \multicolumn{2}{|c|}{ ANOVA } \\
\cline { 1 - 3 } & 10.88 & & F & p- value \\
\hline Caries free & 9.27 & 0.628 & 168.58 & $<0.001^{*}$ \\
\hline Caries active & 8.24 & 0.624 & & \\
\hline Group I & 5.45 & 1.047 & & \\
\hline Group II & & 0.767 & & \\
\hline Group III & & & & \\
\hline
\end{tabular}

$* \mathrm{p}<0.05$ statistically significant.

Table 3b. Pair wise comparison of salivary immunoglobulin level among caries free and caries active groups.

\begin{tabular}{|c|c|c|c|c|c|c|c|}
\hline & \multirow[t]{2}{*}{ (I) Group } & \multirow[t]{2}{*}{ (J) Group } & \multirow{2}{*}{$\begin{array}{c}\text { Mean } \\
\text { Difference } \\
\text { (I-J) }\end{array}$} & \multirow[t]{2}{*}{$\begin{array}{l}\text { Std. } \\
\text { Error }\end{array}$} & \multirow[t]{2}{*}{ p-value } & \multicolumn{2}{|c|}{$\begin{array}{l}\text { 95\% Confidence } \\
\text { Interval }\end{array}$} \\
\hline & & & & & & $\begin{array}{l}\text { Lower } \\
\text { Bound }\end{array}$ & $\begin{array}{l}\text { Upper } \\
\text { Bound }\end{array}$ \\
\hline \multirow{6}{*}{$\begin{array}{l}\text { Ig A } \\
\text { level }\end{array}$} & \multirow{3}{*}{$\begin{array}{c}\text { Caries } \\
\text { free }\end{array}$} & Group I & 1.612 & 0.248 & $<0.001^{*}$ & 0.959 & 2.264 \\
\hline & & Group II & 2.635 & 0.248 & $<0.001^{*}$ & 1.982 & 3.287 \\
\hline & & Group III & 5.429 & 0.248 & $<0.001^{*}$ & 4.776 & 6.081 \\
\hline & \multirow[t]{2}{*}{ Group I } & Group II & 1.023 & 0.248 & $0.001 *$ & 0.370 & 1.676 \\
\hline & & Group III & 3.817 & 0.248 & $<0.001^{*}$ & 3.164 & 4.470 \\
\hline & Group II & Group III & 2.794 & 0.248 & $<0.001^{*}$ & 2.141 & 3.447 \\
\hline
\end{tabular}

Tukey Post Hoc test, ${ }^{*} \mathrm{p}<0.05$ statistically significant, $\mathrm{p}>0.05$ Non significant, NS

dL. In caries active group mean values were group I $(9.27 \mathrm{mg} / \mathrm{dL})$, group II $(8.24 \mathrm{mg} / \mathrm{dL})$ and group III $(5.45 \mathrm{mg} / \mathrm{dL})$ respectively. It was shown that IgA levels in caries active group decreased with increase in caries prevalence. There was a significant difference in the salivary immunoglobulin levels among the study groups $(\mathrm{p}<0.05)$ (Table $3 a)$.

On pair wise comparison the difference in the immunoglobulin levels were found to be statistically significant between all the study groups (Table 3b).

\section{Salivary mucin levels}

The mean salivary mucin value in caries free group was $1.19 \mathrm{mg} /$ $\mathrm{ml}$. In caries active group mean salivary mucin levels were group I ( 1.20 $\mathrm{mg} / \mathrm{ml})$, group II $(1.69 \mathrm{mg} / \mathrm{ml})$ and group III $(2.05 \mathrm{mg} / \mathrm{ml})$ respectively. It was shown that salivary mucin levels in caries active group increased with increase in caries prevalence. There was a significant difference in the salivary mucin levels among the study groups $(\mathrm{p}<0.05)$ (Table $4 \mathrm{a})$.

On pair wise comparison the difference in mucin levels were found to be statistically significant between all the study groups except between caries free group and group I (Table $4 \mathrm{~b}$ ).

\section{Salivary C-reactive protein}

The mean salivary $\mathrm{C}$ - reactive protein value in caries free group was $0.69 \mathrm{mg} / \mathrm{L}$. In caries active group mean C- reactive protein levels in group I $(0.63 \mathrm{mg} / \mathrm{L})$, group II $(0.69 \mathrm{mg} / \mathrm{L})$ and group III $(1.85$ $\mathrm{mg} / \mathrm{L}$ ) respectively It was shown that C-reactive protein level in caries active group increased with increase in caries prevalence. There was a significant difference in the $\mathrm{C}$ - reactive protein levels among the study groups $(\mathrm{p}<0.05)$ (Table $5 \mathrm{a})$.

On pair wise comparison the difference in C- reactive protein levels were found to be statistically significant between study groups. Except for caries free group with group I and between Group I and group II (Table 5b).

\section{Salivary albumin globulin ratio}

The mean salivary Albumin Globulin ratio value in caries free group was $1.23 \mathrm{~g} / \mathrm{dL}$. In caries active group mean salivary albumin globulin ratio levels were group I $(0.92 \mathrm{~g} / \mathrm{dL})$, group II $(0.39 \mathrm{~g} / \mathrm{dL})$ and

Table 4a. Salivary mucin levels in caries free and caries active group.

\begin{tabular}{|l|c|c|c|c|}
\hline & $\begin{array}{c}\text { Salivary immunoglobulin } \\
\text { levels (mg/d) }\end{array}$ & S.D & \multicolumn{2}{|c|}{ ANOVA } \\
\cline { 1 - 3 } & 1.19 & & F & p- value \\
\hline Caries free & 1.20 & 0.200 & 90.88 & $<0.001^{*}$ \\
\hline Caries active & 1.69 & 0.151 & & \\
\hline Group I & 2.05 & 0.179 & & \\
\hline Group II & \multicolumn{2}{|l|}{} & & \\
\hline Group III & & 0.240 & & \\
\hline
\end{tabular}

${ }^{*} \mathrm{p}<0.05$ statistically significant.

Table 4b. Pair wise comparison of salivary mucin level in caries free and caries active groups.

\begin{tabular}{|l|c|l|c|c|c|c|c|}
\hline & $\begin{array}{c}\text { (I) } \\
\text { Group }\end{array}$ & (J) Group & $\begin{array}{c}\text { Mean } \\
\text { Difference } \\
\text { (I-J) }\end{array}$ & $\begin{array}{c}\text { Std. } \\
\text { Error }\end{array}$ & p-value & \multicolumn{2}{|c|}{$\begin{array}{c}\text { 95\% Confidence } \\
\text { Interval }\end{array}$} \\
\hline \multirow{2}{*}{ Mucin } & $\begin{array}{c}\text { Caries } \\
\text { free }\end{array}$ & Group I & -0.009 & 0.062 & $0.99(\mathrm{NS})$ & -0.171 & 0.154 \\
\cline { 3 - 8 } & & Group II & -0.501 & 0.062 & $<0.001^{*}$ & -0.663 & -0.338 \\
\cline { 3 - 8 } & & Group III & -0.860 & 0.062 & $<0.001^{*}$ & -1.022 & -0.697 \\
\hline \multirow{2}{*}{ Group I } & Group II & -0.492 & 0.062 & $<0.001^{*}$ & -0.654 & -0.330 \\
\cline { 3 - 8 } & & Group III & -0.851 & 0.062 & $<0.001^{*}$ & -1.014 & -0.689 \\
\hline \multirow{2}{*}{ Group II } & Group III & -0.359 & 0.062 & $<0.001^{*}$ & -0.522 & -0.197 \\
\hline
\end{tabular}

Tukey Post Hoc test, ${ }^{*} \mathrm{p}<0.05$ statistically significant, $\mathrm{p}>0.05$ Non significant, NS

Table 5a: Salivary C- reactive protein levels in caries freeand caries active group.

\begin{tabular}{|l|c|c|c|c|}
\hline & $\begin{array}{c}\text { Salivary immunoglobulin } \\
\text { levels (mg/d) }\end{array}$ & S.D & \multicolumn{2}{|c|}{ ANOVA } \\
\cline { 1 - 3 } & 0.69 & & F & p- value \\
\hline Caries free & & 0.456 & 32.01 & $<0.001^{*}$ \\
\hline Caries active & 0.65 & 0.412 & & \\
\hline Group I & 0.69 & 0.406 & & \\
\hline Group II & 1.85 & 0.573 & & \\
\hline Group III & & & \\
\hline
\end{tabular}

$* \mathrm{p}<0.05$ statistically significant. 
group III $(0.35 \mathrm{~g} / \mathrm{dL})$ respectively. It was shown that mean albumin globulin ratio levels in caries active group decreased with increase in caries prevalence. There was a significant difference in the mean salivary albumin globulin ratio levels among the study groups $(\mathrm{p}<0.05)$ (Table 6a).

On pair wise comparison the mean salivary albumin globulin ratio levels were found to be statistically significant between study groups expect between group II and group III (Table 6b).

\section{Interpretation}

Results of the present study suggest that $95 \%$ of proline rich protein bands were observed in caries free group and $65 \%$ proline rich protein bands in caries active group.

\section{Discussion}

Presence of abundant proteins in human saliva such as amylases, proline rich proteins, statherin, histatin, mucin and cystatins create an opportunity to extensively study salivary proteome [1419]. Modifications in this proteome composition indicate various physiological and pathological fluctuations [20].

In this study we evaluated salivary total protein, sIg A levels, Mucin

Table 5b. Pair wise comparison of salivary C- reactive protein levels among caries free and caries active groups.

\begin{tabular}{|c|c|c|c|c|c|c|c|}
\hline & \multirow[t]{2}{*}{$\begin{array}{c}\text { (I) } \\
\text { Group }\end{array}$} & \multirow[t]{2}{*}{ (J) Group } & \multirow{2}{*}{$\begin{array}{c}\text { Mean } \\
\text { Difference } \\
\text { (I-J) }\end{array}$} & \multirow[t]{2}{*}{$\begin{array}{l}\text { Std. } \\
\text { Error }\end{array}$} & \multirow[t]{2}{*}{ p-value } & \multicolumn{2}{|c|}{$\begin{array}{l}\text { 95\% Confidence } \\
\text { Interval }\end{array}$} \\
\hline & & & & & & $\begin{array}{l}\text { Lower } \\
\text { Bound }\end{array}$ & $\begin{array}{l}\text { Upper } \\
\text { Bound }\end{array}$ \\
\hline \multirow{6}{*}{$\begin{array}{c}\mathrm{C}- \\
\text { rpLevel }\end{array}$} & \multirow{3}{*}{$\begin{array}{c}\text { Caries } \\
\text { free }\end{array}$} & Group I & 0.067 & 0.147 & $0.97(\mathrm{NS})$ & -0.320 & 0.455 \\
\hline & & Group II & -0.001 & 0.147 & $1.00(\mathrm{NS})$ & -0.389 & 0.386 \\
\hline & & Group III & -1.156 & 0.147 & $<0.001^{*}$ & -1.544 & -0.769 \\
\hline & \multirow[t]{2}{*}{ Group I } & Group II & -0.069 & 0.147 & $0.97(\mathrm{NS})$ & -0.456 & 0.319 \\
\hline & & Group III & -1.224 & 0.147 & $<0.001^{*}$ & -1.611 & -0.836 \\
\hline & Group II & Group III & -1.155 & 0.147 & $<0.001^{*}$ & -1.542 & -0.768 \\
\hline
\end{tabular}

Tukey Post Hoc test, ${ }^{*} \mathrm{p}<0.05$ statistically significant, $\mathrm{p}>0.05$ Non significant, NS

Table 6a. Salivary Albumin Globulin ratio levels in caries free and caries active group.

\begin{tabular}{|l|c|c|c|c|}
\hline & $\begin{array}{c}\text { Salivary immunoglobulin } \\
\text { levels (mg/dl) }\end{array}$ & S.D & \multicolumn{2}{|c|}{ ANOVA } \\
\cline { 1 - 3 } & 1.23 & & F & p- value \\
\hline Caries free & 0.92 & 0.384 & 31.42 & $<0.001^{*}$ \\
\hline Caries active & 0.39 & 0.509 & & \\
\hline Group I & 0.35 & 0.237 & & \\
\hline Group II & \multicolumn{2}{|c|}{} & & \\
\hline Group III & & 0.129 & & \\
\hline
\end{tabular}

${ }^{*} \mathrm{p}<0.05$ statistically significant.

Table 6b. Pair wise comparison of salivary Albumin Globulin ratio levels in caries free and caries active group.

\begin{tabular}{|c|c|c|c|c|c|c|c|}
\hline & \multirow[t]{2}{*}{$\begin{array}{c}\text { (I) } \\
\text { Group }\end{array}$} & \multirow[t]{2}{*}{ (J) Group } & \multirow{2}{*}{$\begin{array}{c}\text { Mean } \\
\text { Difference } \\
\text { (I-J) }\end{array}$} & \multirow[t]{2}{*}{$\begin{array}{l}\text { Std. } \\
\text { Error }\end{array}$} & \multirow[t]{2}{*}{ p-value } & \multicolumn{2}{|c|}{$\begin{array}{l}\text { 95\% Confidence } \\
\text { Interval }\end{array}$} \\
\hline & & & & & & $\begin{array}{l}\text { Lower } \\
\text { Bound }\end{array}$ & $\begin{array}{l}\text { Upper } \\
\text { Bound }\end{array}$ \\
\hline \multirow{6}{*}{$\begin{array}{c}\text { AG } \\
\text { ratio }\end{array}$} & \multirow{3}{*}{$\begin{array}{l}\text { Caries } \\
\text { free }\end{array}$} & Group I & 0.315 & 0.110 & $0.03 *$ & 0.027 & 0.603 \\
\hline & & Group II & 0.841 & 0.110 & $<0.001^{*}$ & 0.553 & 1.129 \\
\hline & & Group III & 0.907 & 0.110 & $<0.001^{*}$ & 0.620 & 1.195 \\
\hline & \multirow[t]{2}{*}{ Group I } & Group II & 0.526 & 0.110 & $<0.001 *$ & 0.238 & 0.814 \\
\hline & & Group III & 0.592 & 0.110 & $<0.001 *$ & 0.305 & 0.880 \\
\hline & Group II & Group III & 0.066 & 0.110 & $0.93(\mathrm{NS})$ & -0.222 & 0.354 \\
\hline
\end{tabular}

Tukey Post Hoc test, ${ }^{*} \mathrm{p}<0.05$ statistically significant, $\mathrm{p}>0.05$ Non significant, NS levels, C-reactive protein, A/G ratio and proline rich proteins.

Major salivary protein constitutes more than $95 \%$ of the total protein content [21]. Various Studies have compared relationship between dental caries and salivary total protein levels, this study showed mean salivary protein of $2.03 \mathrm{~g} / \mathrm{dl}$ in control group which increased significantly in comparison with the high caries group, it may be attributed to the protective effect of salivary proteins against free diffusion of acids on the tooth surface, thus providing protection against occurrence of dental caries [2].

Role of salivary protein is explained as "double edged swords" i.e., they may play a protective role depending on their site, location and action, or may increase colonization of microorganism [18]. De-farias DG and Bezerra AC (2003) conducted a study to evaluate mean protein levels in early childhood caries in comparison with caries free subjects showed no significant increase in total protein content between two groups. Similar results were reported by Roa $e t$ al.

Salivary immunoglobulin's (>85\%) primarily are IgA and come under secretory IgA subclass. They are made up of multiple peptide, they comprise $5-15 \%$ of total salivary proteins [2].

In this study IgA decreased with increase in caries prevalence. This may be suggestive of its high specific binding feature to microbial species and neutralizing action. Thus, prevents bacterial adhesion, colonization on tooth surface providing protection against dental caries [21-26].

Similar results were reported by Doifode D and Damle SG (2011) conducted by study on comparing IgA levels in saliva among caries free and caries active children's showed similar result as this study. Similarly Gregory et al., (1990) also reported similar results and explained this difference in IgA levels may be due to increased production of IgA antibodies against Streptococcus Mutans in caries free than caries active childrens. Hedge et al., (2013) also showed increase in IgA in caries free individuals in comparison to caries active individuals.

In contrast studies conducted by Krasse B, et al. (1987) reported salivary IgA levels and dental caries were inversely correlated .Ranadheer E, et al. (2008)conducted similar study among children's and showed an increase in IgA among caries free individuals than caries active individuals, it may be a suggestive of the defensive mechanism against S.mutans in whole saliva [27].

An important constitute of salivary glycoprotein is mucin. Human saliva consists of atleast two distinct type of mucin; lower molecular weight MUC7 and high molecular weight MUC5B [28].

These secreted mucin due to its hydrophilic properties lubricate, protect oral tissue surface by modulating oral micro-organism [15]. In this study mucin levels increased with increase in caries prevalence. This increase may be attributed to increase in production of mucin during caries development as a protective mechanism, thereby protecting tooth surface from desiccation and insults [21].

Similar result were observed by Gabryel-Porowska et al., (2014) were role of specific mucin like MUC5B, MUC7 and MUC1 in saliva of children's was compared with dental caries. They showed the role of membrane bound MUC1 and gel forming MUC 5B, which would strengthen epithelial protective barrier and stabilizes mucin in oral cavity for longtime [29-32].

C-reactive protein increases in serum with systemic inflammation [21]. Pedersson et al., (1990) showed a high acute phase protein (C-RP) 
levels in individuals with gingivitis, severe and moderate periodontitis. DE Soet et al., (2003) showed relationship between acute phase protein and high caries index.

In this study C-reactive protein was high in group III which was significantly higher in comparison with other groups. This may be attributed to the immune response during caries progression, development and thus indicative of inflammation. Similar results were concluded by Gawri et al., (2012).

Salivary albumin concentration is always a marker for severity of underlying disease or inflammation [2]. Various studies have concluded that the albumin has inhibitory effect on enamel demineralization by penetrating into the enamel pores [33]. The results of present study showed a variation in albumin globulin ratio between high caries group and control group. This may be suggestive of underlying inflammation in high caries group. These results are in accordance with studies conducted by Hedge et al., (2014) and Muncia et al., (2008) they concluded a high albumin levels with decrease in level of caries.

Proline rich proteins make up almost $15-20 \%$ of salivary proteins [5]. Various studies were conducted to conclude the relationship between salivary proline rich proteins and caries, but still remains inconclusive [6]. A study conducted showed larger proline rich protein's among caries free individuals and individuals with severe caries (Ayad M, Van Wuyckhuyse BC and Minaguchi K, 2000).

According to Nobbs et al,. (2011) the proline rich proteins in whole saliva attach to $S$. mutans through major adhesion antigen and this particular immunogen mixture protects the tooth from caries [3436]. Levine $M$ (2011) explained that larger available basic proline rich proteins lead to increase in basic PRP residues which attach to the acid producing streptococci, thus neutralizing them.

In this study electrophoresis separation showed a variation in patterns among caries free and caries active group. The variability in protein profiles suggest a protective role of proline rich proteins [16]. Among total of 80 subjects $95 \%$ of proline rich proteins bands were observed in caries free and $65 \%$ proline rich protein bands in caries active group [37,38].

This study is in accordance with study conducted by Tenovuo et al., (1992) suggesting their protective action, in the remineralisation process, i.e., known as "enamel precursor role", which is in agreement with study reported by Banderas-Tarabay et al., (2002). Bhalla et al., (2010) conducted a similar study to analyse correlation between salivary proteins and early childhood caries and showed protective role of this protein (Figures 1 and 2).

This study showed protective role of certain salivary proteins. Understanding the role of other proteins could be done in future for better relevance and conclusion.

However, limitations of this study are that only certain salivary proteins were evaluated, other minor and major salivary proteins like histatins, statherins can also be evaluated. Various groups of mucins depending on their molecular weight can be measured since they have varying role instead of whole mucin concentration in the saliva.

In this study saliva samples were collected based on No. of decay in the oral cavity, further studies with extent of decay i.e enamel caries, dentinal caries, deep dentinal caries and involvement of pulp would help in evaluating better relevance between salivary proteins and extent of dental caries.

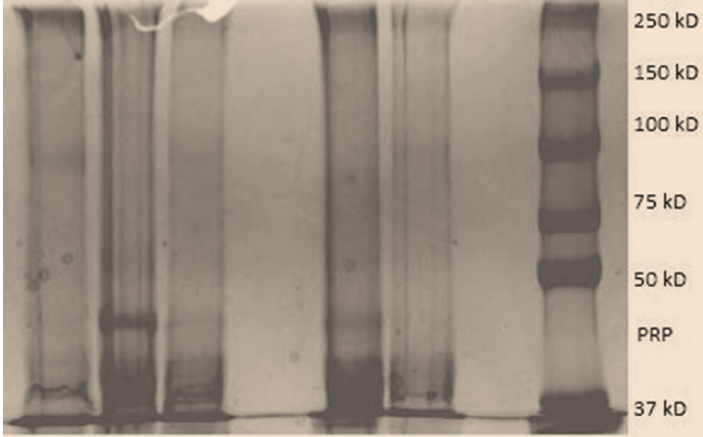

$$
\begin{array}{llllll}
\text { G3 } & \text { G1 } & \text { G2 } & \text { G1 } & \text { G3 } & \text { M }
\end{array}
$$

Figure 1. SDS-PAGE of salivary protein. Note: M(Protein Marker) PRP(Proline rich protein) G 1 (Patients with 1-4 caries), G 2(Patients with 5-9 caries) G 3(Patient with $>10$ carries).

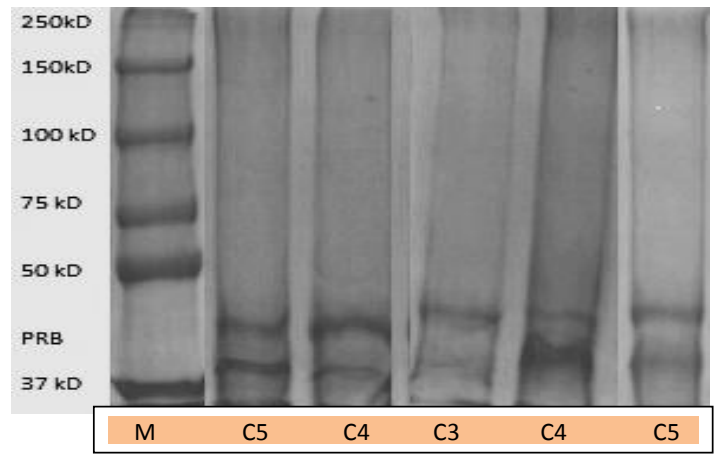

Figure 2. SDS-PAGE of the salivary protein of control samples. Note: M (Protein Marker) PRP (Proline rich protein), C 1-5 (Control Samples).

From this study following conclusion could be drawn:

1- Salivary total protein levels were significantly high in caries free group in comparison with caries active group.

2- $\quad$ Salivary $\operatorname{IgA}$ levels were statistically significant in caries free group in comparison to caries active group.

3- Salivary Mucin levels showed significantly high levels in caries active group group in comparison to caries free group.

4- Salivary albumin globulin ratio was significantly high in control group in comparison to caries active group.

5- $\quad$ Salivary C-reactive protein levels were significantly high in caries active group in comparison to caries free group.

6- $95 \%$ of proline rich protein bands in control group, in comparison to caries active group which showed $65 \%$ of proline rich protein bands.

There are various salivary components that are thought to play a defensive role in oral cavity $[39,40]$. Further studies, with larger sample size and better molecular epidemiology of these salivary proteins will be more helpful in improving methodology and proving salivary proteins are efficient biomarkers for dental caries.

\section{Acknowledgement}

Authors appreciate the assistance provided by Central Research Laboratory, K.S.Hegde Medical Academy, Nitte University, Deralkatte, Mangalore. 


\section{Declaration of interest}

NIL.

\section{References}

1. Martins C, Buczynski AK, Maia LC, Siqueira WL, Castro GF (2013) Salivary proteins as a biomarker for dental caries--a systematic review. J Dent $41: 2-8$. [Crossref]

2. Van Nieuw Amerongen A, Bolscher JG, Veerman EC (2004) Salivary proteins: protective and diagnostic value in cariology? Caries Res 38: 247-253. [Crossref]

3. Levine $\mathrm{M}$ (2011) Susceptibility to dental caries and the salivary proline-rich proteins. Int J Dent 2011: 953412. [Crossref]

4. Fuentes L, Yakob M, Wong DT (2014) Emerging horizons of salivary diagnostics for periodontal disease. Br Dent J 217: 567-573. [Crossref]

5. Bhalla S, Tandon S, Satyamoorthy K (2010) Salivary proteins and early childhood caries: A gel electrophoretic analysis. Contemp Clin Dent 1: 17-22. [Crossref]

6. Gorr SU (2009) Antimicrobial peptides of the oral cavity. Periodontol 2000 51: $152-$ 180. [Crossref]

7. Guare RO, Ciamponi AL, Teresa M, Santos BR, Gorjao R, et al. (2013) Caries experience and salivary parameters among overweight children and adolescents. Dent $J 1: 31-40$.

8. Tao R, Jurevic RJ, Coulton KK, Tsutsui MT, Roberts MC, et al. (2005) Salivary antimicrobial peptide expression and dental caries experience in children. Antimicrob Agents Chemother 49: 3883-3888. [Crossref]

9. Hegde MN, Hegde ND, Ashok A, Shetty S (2014) Biochemical indicators of dental caries in saliva: an in vivo study. Caries Res 48: 170-173. [Crossref]

10. Krasteva A, Kisselova A (2011) Salivary acute phase proteins as biomarker in oral and systemic disease, acute phase proteins as early non-specific biomarkers of human and veterinary diseases.

11. Guo L, Shi W (2013) Salivary biomarkers for caries risk assessment. J Calif Dent Assoc 41: 107-109, 112-118. [Crossref]

12. Hedge MN, Bhat R, Punja A, Shetty C (2014) Correlation between dental caries and salivary Albumin in adult Indian population- an in vivo study. British journal of medicine and medical research 4: 4238-4244.

13. Shimotoyodome A, Kobayashi H, Tokimitsu I, Matsukubo T, Takaesu Y (2006) Statherin and histatin 1 reduce parotid saliva-promoted streptococcus mutans strain MT8148 adhesion to hydroxyapatite surfaces. Caries Res 40: 403-411.

14. Kaufman E, Lamster IB (2002) The diagnostic applications of saliva--a review. Crit Rev Oral Biol Med 13: 197-212. [Crossref]

15. Gabryel-Porowska H, Gornowicz A, Bielawska A, Wójcicka A, Maciorkowska E, et al. (2014) Mucin levels in saliva of adolescents with dental caries. Med Sci Monit 20: 72-77. [Crossref]

16. Beeley JA (1991) Clinical applications of electrophoresis of human salivary proteins. $J$ Chromatogr 569: 261-280. [Crossref]

17. Doifode D, Damle SG (2011) Comparison of salivary Ig A levels in caries free and caries active children. Journal of Clinical Dental Science 2: 10-14.

18. Vibhakar PA, Patankar SR, Yadav MR, Vibhakar PA (2013) Salivary total protein levels and their correlation to dental caries. International Journal of Oral \& Maxillofacial Pathology 4: 13-16.

19. Loo JA, Yan W, Ramachandran P, Wong DT (2010) Comparative human salivary and plasma proteomes. J Dent Res 89: 1016-1023. [Crossref]

20. Kościelniak D, Jurczak A, Zygmunt A, Krzyściak W (2012) Salivary proteins in health and disease. Acta Biochim Pol 59: 451-457. [Crossref]

21. Helmerhorst EJ, Oppenheim FG (2007) Saliva: a dynamic proteome. J Dent Res 86 : 680-693. [Crossref]

22. de Farias DG, Bezerra AC (2003) Salivary antibodies, amylase and protein from children with early childhood caries. Clin Oral Investig 7: 154-157. [Crossref]

23. Roa NS, Chaves M, Gómez M, Jaramillo LM (2008) Association of salivary proteins with dental caries in a Colombian population. Acta Odontol Latinoam 21: 69-75. [Crossref]

24. Gregory RL, Kindle JC, Hobbs LC, Filler SJ, Malmstrom HS (1990) Function of anti-streptococcus mutans antibodies: Inhibition of virulence factors and enzyme neutralization. Oral Mirobial Immonol 5: 181-188.

25. Hegde MN, Devadiga D, Shetty C, Shetty A (2013) Correlation between dental caries and salivary immunoglobulin in adult Indian population: An in vivo study. Journal of Restorative Dentistry 1: 22-25.

26. CamlingE, Gahnberg L, KrasseB (1987) The Relationship between Ig antibodies to streptococcus mutans antigens in human saliva and breast milk and the number of indigenous oral streptococcus mutans. Arch Oral Biol 32: 21-25.

27. Ranadheer E, Nayak UA, Reddy NV, Rao VA (2011) The relationship between salivary IgA levels and dental caries in children. J Indian Soc Pedod Prev Dent 29: 106-112. [Crossref]

28. Rousseau K, Wickstrom C, Whitehouse DB, Carlstedt I, Swallow DM (2003) New monoclonal antibodies to non-glycosylated domains of the secreted mucins MUC5B and MUC7. Hybrid Hybridomics 22: 293-299. [Crossref]

29. Iyengar A, Paulus JK, Gerlanc DJ, Maron JL (2014) Detection and potential utility of C-reactive protein in saliva of neonates. Front Pediatr 2: 131. [Crossref]

30. Pederson E, Stanke S, Whitener S (1990) Salivary levels of 2-macrolobulin,alpha antitrypsin, C-reactive protein, cathepsin $\mathrm{G}$ and elastase in human with or without destructive periodontal disease. Archives of oral biology 40: 1151-1155.

31. de Soet JJ, Schriks MC, Kratz E, Poland DC, van Dijk W, et al. (2003) Dental caries related to plasma IgG and alpha1-acid glycoprotein. Caries Res 37: 79-84. [Crossref]

32. Gawri S, Shukla P, Chandrakar A (2012) A survey of micro flora present in dental caries and it's relation to environmental factors. Science and Technology 4: 09-12.

33. van der Linden AH, Booij M, ten Bosch JJ, Arends J (1989) Albumin interaction with caries-like lesions in bovine enamel. Caries Res 23: 393-398. [Crossref]

34. Mungia R, Cano SM, Johnson DA, Dang H, Brown JP (2008) Interaction of age and specific saliva component output on caries. Aging Clin Exp Res 20: 503-508. [Crossref]

35. Ayad M, Van Wuyckhuyse BC, Minaguchi K, Raubertas RF, Bedi GS, et al. (2000) The association of basic proline-rich peptides from human parotid gland secretions with caries experience. J Dent Res 79: 976-982. [Crossref]

36. Nobbs AH, Jenkinson HF, Jakubovics NS (2011) Stick to your gums: mechanisms of oral microbial adherence. J Dent Res 90: 1271-1278. [Crossref]

37. Tenovuo J, Jentsch H, Soukka T, Karhuvaara L (1992) Antimicrobial factors of saliva in relation to dental caries and salivary levels of mutans streptococci. J Biol Buccale 20 : 85-90. [Crossref]

38. Banderas-Tarabay JA, Zacarías-D’Oleire IG, Garduño-Estrada R, Aceves-Luna E, González-Begné M (2002) Electrophoretic analysis of whole saliva and prevalence of dental caries. A study in Mexican dental students. Arch Med Res 33: 499-505. [Crossref]

39. Kirstila V, Hakkinen P, Jentsch H, Vilja P, Tenovuo J (1998) Longitudinal analysis of the association of human salivary antimicrobial agents with caries increment and cariogenic micro-organisms: a two-year cohort study. J Dent Res 77: 73-80. [Crossref]

40. He F. Laemmli-SDS-PAGE. .Available from: Http://www.bio-protocol.org/e80

Copyright: (C)2017 Nireeksha. This is an open-access article distributed under the terms of the Creative Commons Attribution License, which permits unrestricted use, distribution, and reproduction in any medium, provided the original author and source are credited. 